\title{
KENZÜ'L-KÜBERÂ YAYININA BAZI KATKILAR
}

\author{
Bilal ÇAKICI* \\ Ahmet KARADOĞAN**
}

$\ddot{O} z$

Şeyhoğlu Mustafa (ö. 817/1414?)'nın Kenzü'l-Küberâ ve Mehekkü'lUlemâ (Büyüklerin Hazinesi ve Âlimlerin Mihenk Taşı) adlı eseri, Yusuf Has Hacib'in Kutadgu Bilig'inden sonra yazllan, siyasetname türündeki bilinen ikinci eserdir. Bu eser, Eski Anadolu Türkçesinin dil özelliklerini yansıtması, Anadolu nesrinin gelişimine dair veriler sunmast ve elde bulunan tek yazma nüshasının harekeli olması yönüyle Türk dili tarihi açısından önem taşımaktadır. Söz konusu eser; çeviri yazılı metni, metnin günümüz Türkçesine aktarımı, incelemesi ve tıpkıbasımıyla Kemal Yavuz tarafindan yayımlanmıştır. Bu yayında Kenzü'l-Küberâ'nın yazma nüshasının $1 b$ ve $2 a$ sayfasindaki deformasyon sebebiyle bazl yerler okunamayarak bos bırakılmış, metnin bütününde ise kimi kelimeler yanlış okunmuş veya atlanmıştır. Bu yazıda öncelikle ilk yapraklardaki okunamayan yerler, metin tamiri yöntemleriyle okunmaya çalışılmış; metnin tamamı tarafimızca gözden geçirilerek dikkati çeken yanlı̧̧ okumalar düzeltilmiş, eksiklikler ise tamamlanmıştır.

Anahtar Kelimeler: Eski Anadolu Türkçesi, Kenzü'l-küberâ, Metin Neşri, Metin Tamiri.

\section{SOME CONTRIBUTIONS TO THE PUBLICATION OF THE KENZÜ'L-KÜBERÂ}

\author{
Abstract \\ Sheikhoglu Mustafa (died: 1414?)'s Kenzü'l-Küberâ ve Mehekkü'l- \\ Ulemâ (The Treasure of Ancestors and the Cornerstone of Savants), is

\footnotetext{
* Doç. Dr., Ankara Üniversitesi, DTCF, Türk Dili ve Edebiyatı Bölümü, ORCİD: 0000-0001-8871-3870

e-posta: cakicib@ankara.edu.tr

** Prof. Dr., Kırıkkale Üniversitesi, Fen-Edebiyat Fakültesi, Türk Dili ve Edebiyatı Bölümü, ORCID: 0000-0003-3621-0440

e-posta: ahkaradogan@yahoo.com
}

Geliş / Received: 1 Mart / March 2021

Kabul / Accepted: 5 Mart / March 2021 
known to be the second "Siyasetnameh" (political treatise) to have been written after Yusuf Khass Hajib's "Kutadgu Bilig". This book is of particular importance in terms of the history of Turkish language in so far as it not only reflects the characteristics of ancient Anatolian Turkish and offers key data as to the evolution of Anatolian prose, but also because the only existing manuscript version thereof features vowel points ("hareke"). The transcript text and translation of the afore-mentioned work into contemporary Turkish language as well as its analysis and original version was published by Kemal Yavuz. While due to some alterations on pages $1 \mathrm{~b}$ and $2 a$ of the manuscript version of the Kenzü'l-Küberâ, this publication, some parts were left empty as they were illegible, some parts were misread or forgotten in the overall text. Hence, this article firstly undertakes to read/decipher the unreadable parts referred to above based on text repair principles while also reviewing the whole text to correct striking misreadings and adding the missing parts.

Keywords: Ancient Anatolian Turkish, Kenzü'l-küberâ, Text Editing, Text Repair.

Şeyhoğlu'nun, Germiyan ve Osmanlı saraylarındaki tecrübelerini aktarmak amaciyla siyasetname türünde kaleme aldığı Kenzü'l-Küberâ, Yusuf Has Hacib'in Kutadgu Bilig'inden sonra yazıldığ bilinen ikinci siyasetname olma özelliğine sahiptir. Elde bulunan tek nüshasının harekeli olması ve eserin Eski Anadolu Türkçesinin dil özelliklerini yansıtması, bu eseri Türk dili tarihi açısından değerli bir yere taşımaktadır. Anadolu nesrinin gelişimine dair önemli veriler de sunan bu eser; çeviri yazılı metni, metnin günümüz Türkçesine aktarımı, incelemesi ve tıpkıbasımıyla Kemal Yavuz tarafından araştırmacıların ve günümüz okurlarının istifadesine sunulmuştur [Şeyhoğlu Mustafa (2013). Kenzü'l-Küberâ ve Mehekkü'lUlemâ (Büyüklerin Hazinesi ve Âlimlerin Mihenk Taşı), haz. Kemal Yavuz. İstanbul: Büyüyen Ay Yayınları.].

Büyük bir emeğin ürünü olarak ortaya çıkan bu yayında Kenzü'lKüberâ'nın yazma nüshasının $1 \mathrm{~b}$ ve $2 \mathrm{a}$ sayfalarındaki deformasyon sebebiyle bazı yerlerin okunamayarak boş bırakıldığı, metnin bütününde ise dikkatsizlikten kaynaklandığı düşünülen bazı yanlış okumaların varlığ dikkati çekmektedir. Biz bu yazıda öncelikle ilk yapraklardaki okunamadığı için eksik kalan yerleri, metin tamiri yöntemleri dairesinde, tamamlamaya çalıştık. Metnin bütününde dikkatimizi çeken yanlışları ise "Doğru/Yanlış Cetveli”yle dikkatlere sunduk. Böylece ilk olarak 1991'de, ikinci defa ilavelerle 2013'te yayımlanan bu eserin gelecek baskılarına karınca kararınca katkıda bulunmayı istedik.

Yazmanın besmele ve hamdele kısımlarının yer aldığ $1 \mathrm{~b}$ ve $2 \mathrm{a}$ sayfalarındaki, çeşitli sebeplerle okunamayan yerlerin; manzum kısımlarda vezin, kafiye ve anlam imkânlarından; mensur kısımlarda ise siyak ve sibaka göre, yazarın üslubundan da yararlanarak olabildiğince tamamlanması yoluna gidilmiştir. Karşılaştırma yapılabilmesi için ilgili sayfaların tıpkıbasımdaki görüntüleri, yazımızın sonuna eklenmiştir. Metnin 
bütünlüğünü bozmamak için bu sayfaların tamamının çeviri yazısı yeniden yapılmış, değiştirilen veya ilk defa okunan yerlere ilişkin açıklamalar ise dipnot olarak verilmiştir. Kemal Yavuz Yayını'nda (=KYY) olmayan, tarafimızdan ilk defa teklif edilen okuyuşlar köşeli ayraç içinde ve koyu; KYY ile farklı okuyuşlarımız ise sadece koyu olarak gösterilmiştir.

Söz konusu sayfaların çeviri yazısını vermeden önce, KYY'nin çeviri yazısıyla ilgili dikkatimizi çeken bazı hususları da belirtmek isteriz:

Çeviri yazıda damak n'lerinin bazen gösterilmesi bazen gösterilmemesi, bazen ng biçiminde bazen ñ biçiminde gösterilmesi; uzun ünlülerin kâh düzeltme $\left(^{\wedge}\right)$ işaretiyle kâh düz çizgiyle gösterilmesi, kimi zaman da gösterilmemesi gibi çeviri yazı işaretleriyle ilgili çok sayıda tutarsızlık ve ihmal vardır. Çeviri yazıda özgün biçimde bırakılan ayet, hadis gibi Arap harfli kısımların, satır değiştiğinde, teknik sebeplerle dizgisinin karıştığı, dolayısıyla metnin bütünlüğünün bozulduğu; 19b sayfasının -çeviri yazısı yapılmakla beraber- tıpkıbasımda yer almadığı görülmektedir.

Metnin $1 b$ ve 2a sayfalarının çeviri yazısı şöyledir:

[1b]

$1 \quad$ [Kenzü'l-Küberā $]^{1}$

2 Bismillāhi'r-rahmāni'r-rahīm ve bihī neste ' $\overline{\mathbf{i n}}^{2}$

3 Şükür ve sipās-1 bī-ḳıyās ol Tạrı'ya ki niteligün

4 ve niceligün ana yolı yoḳdur ve adları ve șıfatları

5 hisāba gelmez, çoḳdur ${ }^{3}$. Nice ki eydür beyt:

6 Zātınun [keyfiyyetiyçün kimsene] ${ }^{4}$ virmez cevāb

7 [Adları evșāfını kim hịç] ${ }^{5}$ zaāt itmez su'āl

8 'Arş u kürsī [de bulınmaz ana] ${ }^{6}$ mekān u zamān

9 ve ihvān [düzetdiler ki 'āḳillerün 'aḳlı] ${ }^{7}$ ve zīreklerün

10 fikri ve 'ālimlerün ilmi ve mütekellimlerün kelimi ${ }^{8}$

11 ve āriflerün ma'rifeti anun kemāl-i 'ilmine ve cemāl-i

kudretine

[2a]

\footnotetext{
${ }^{1}$ Sayfanın başında yer alan eser adı KYY'de yazılmamıştır.

${ }^{2}$ KYY'de "nest'în".

${ }^{3}$ KYY'de "gelmesi yokdur".

4 KYY'de okunamamıştır. Vezin, anlam ve yazmadaki ipuçları çerçevesinde tarafımızca okunmuştur.

5 KYY'de okunamamıştır. Manzum-mensur metinlerdeki manzum kısımlar, genellikle mensur bölümlerdeki manayı pekiştirme işlevi görmektedir. Bu çerçevede 4 ve 5. satırlar doğrultusunda, yine vezin ve anlama göre tarafimızca okunmuştur. Metin tamirinin sınırlarını zorlayan bu eklemeyi ihtiyatla yaptığımızı belirtmek isteriz.

${ }^{6}$ KYY'de okunamamıştır. Siyak ve sibaka göre tarafimızca okunmuştur.

${ }^{7}$ KYY'de okunamamıştır. Siyak ve sibaka göre tarafimızca okunmuştur.

${ }^{8}$ KYY'de kelîmi.

${ }^{9}$ KYY'de "kemâli 'ilmine ve cemâli kudretine".
} 
1 yol bulmaz ve neden ne oldugin bilmez. Nice ki eydür beyt:

2 Zihì deryā ki 'ālem garạ u ḥayrān

3 Zihī șaḥrā ki yohoudur ${ }^{10}$ ḥadd u pāyān

4 Egerçi kendüsi tamāmet ${ }^{11}$ ḳāyinātdan ${ }^{12}$ [müberrādur] ${ }^{13}$ ve mekāndan mu'arrā

5 ve illā andan hịç yir ḩāli degüldür ki [Allāhu nūru'ssemāvāti

6

var nihānì

ve'l-arż]. ${ }^{14}$ Nice ki eydür beyt: [Ne ansuz bir ḳarış yir $]^{15}$

$7 \quad$ Ne yirde gökde sābitdür mekānı [Bu ibretde $]^{16}$ 'ālem [deng

ü] ${ }^{17}$ hayrān

8

mecmū' 1

9 hūb ve her ne ki [düridürse cemí íi ${ }^{19}$ mergiūb ve kendü

10 bu yaratdugìndan hî̉ birine benzemez ve hịç biri dahı

\begin{tabular}{|l|l|l|}
\hline \multicolumn{2}{|c|}{ Doğru - Yanlış Cetveli } \\
\hline Sayfa & Yanlış & Doğru \\
\hline $202-3 b^{20}$ & yirli yirine & yirlü yirine \\
\hline $202-4 a$ & Cümle 'âlemlere & Cümle-i 'ālemlere \\
\hline $203-4 b$ & Nice xxx ${ }^{21}$ eydür & Nice ki eydür \\
\hline $204-5 a$ & BÂB-I SEVÜM & BĀB-I SivÜM \\
\hline $207-6 b$ & hâşiyyetler görinügelür & hāșiyyetler görinügelür \\
\hline $207-7 a$ & 'atiyyet naz̧arın & ināyet naz̧arın \\
\hline
\end{tabular}

\footnotetext{
${ }^{10}$ KYY'de "yokdur".

${ }^{11}$ KYY'de "tamâmen".

12 KYY'de "kâyinât".

${ }^{13}$ KYY'de okunamamıştır.

${ }^{14}$ KYY'de çeviri yazısı yapılmamıştır. KYY'de Arapça kısımların çeviri yazısı yapılmamıştır. Biz bu kısımların da çeviri yazısının yapılması gerektiği görüşündeyiz.

${ }^{15} \mathrm{KYY}$ 'de okunamamıştır.

${ }^{16} \mathrm{KYY}$ 'de okunamamıştır.

${ }^{17} \mathrm{KYY}$ 'de okunamamıştır.

${ }^{18} \mathrm{KYY}$ 'de okunamamıştır.

${ }^{19} \mathrm{KYY}$ 'de okunamamıştır.

${ }^{20} \mathrm{Bu}$ sütundaki ilk sayı kitaptaki sayfa numarasını, ikincisi ise tıpkıbasımın sayfa numarasını göstermektedir.

${ }^{21}$ Metnin aslında bulunup da KYY'de dikkatsizlik sebebiyle atlanmış olan yerler, " $\mathrm{xxx}$ ” ile gösterilmiştir.
} 


\begin{tabular}{|c|c|c|}
\hline $207-7 a$ & andın yana & andan yana \\
\hline $208-7 b$ & $\begin{array}{l}\text { bu sırlar zâhir olmaz. xxx Şol ay } \\
\text { yüzlü }\end{array}$ & $\begin{array}{l}\text { bu sırlar z̦āhir olmaz. Meșel: } \\
\text { Şol ay yüzlü }\end{array}$ \\
\hline $209-8 a$ & țılsım-ı a'z̧amdur & țılısm-ı a'z̧amdur \\
\hline $209-8 a$ & baḥtına iriştiler & baḩtına irişdiler \\
\hline $209-8 b$ & $\begin{array}{l}\text { mâlikiyyet 'âlemin yuḳaru } \\
\text { götürdiler. }\end{array}$ & $\begin{array}{l}\text { mālikiyyet 'alemin yuḳaru } \\
\text { götürdiler. }\end{array}$ \\
\hline $210-8 b$ & Îsâ çigini üzre & '̄̄si çigini üzre \\
\hline $210-9 a$ & xxx șâhib-himmet kimseneye & bir șāḥib-himmet kimseneye \\
\hline $210-9 a$ & ilâ âyetihi & el-āyetihi \\
\hline $210-9 a$ & Allah sübhâne & Allāh sübhānehu \\
\hline $211-9 b$ & ayruḳlara virirserin & ayruḳlara viriserin \\
\hline $211-10 a$ & sözüñ taḥḳ̂ịıına irişse & sözün taḥkịkıına irişe \\
\hline $211-10 a$ & $\begin{array}{l}\text { Dünyâyı dînüñe șarf eyleyügör } \\
\text { Şeyhoglu }\end{array}$ & $\begin{array}{l}\text { Dünyāyı dīnüne șarf eyleyügör } \\
\text { Şeyḩoġı }\end{array}$ \\
\hline $212-10 a$ & b̧ılāfı xxx olmaya & ḩilāf-ı ḥaḳ olmaya \\
\hline $212-10 b$ & Ancak pâdişâhuñ vardur & Pāżişāhun vardur \\
\hline $213-11 a$ & Muḳâbil eyle & Muḳābel eyle \\
\hline $215-12 a$ & Tañrı yolında & Tayrı yolından \\
\hline $215-12 b$ & hoca Mes'ûd & h้ॅāce Mes'ūd \\
\hline $215-12 b$ & $\begin{array}{l}\text { Ol egri çeker xxx ḳo toġruya } \\
\text { sap }\end{array}$ & $\begin{array}{l}\text { Ol egri çeker sen ḳo toġruya } \\
\text { sap }\end{array}$ \\
\hline $216-12 b$ & Ve xxx unıtmag்uñ & Ve bu unıtmaġuñ \\
\hline $216-13 a$ & Doḳuzıncı ḥaḳ ta'âlâ gösterdi ki & $\begin{array}{l}\text { Dokuzunç ḥaḳ te ālā gösterdi } \\
\text { ki }\end{array}$ \\
\hline $216-13 a$ & Yaġıdan olan saḳlamag்ı & Yaġıdan saḳlamag்ı \\
\hline $216-13 a$ & Onıncı işâretdür & Onınç işāretdür \\
\hline
\end{tabular}




\begin{tabular}{|c|c|c|}
\hline $217-13 b$ & sülük menfa'atlarından & sülūk menfa'atlarından \\
\hline $218-14 a$ & $\begin{array}{l}\text { Dâvûd peyġambara } \\
\text { 'aleyhisselâma eyitdi ki }\end{array}$ & $\begin{array}{l}\text { Dāvūd peyġambar } \\
\text { 'aleyhisselāma eyitdi ki }\end{array}$ \\
\hline $218-14 b$ & $\begin{array}{l}\text { Key bil ki salțanat ulu âletidür } \\
\text { iy emîr }\end{array}$ & $\begin{array}{l}\text { Key bil ki salțanat ulu āletdür } \\
\text { iy emīr }\end{array}$ \\
\hline $218-14 b$ & ìkinci oldur ki & ìkinç oldur ki \\
\hline $219-15 a$ & Üçinci oldur ki & Üçinç oldur ki \\
\hline $219-15 a$ & $\begin{array}{l}\text { tâ‘ata xxx ṣalâḥa daḩı râgııbırak } \\
\text { olalar }\end{array}$ & $\begin{array}{l}\text { tā'ata ve ṣalāḥa daḩı rāġıbıraḳ } \\
\text { olalar }\end{array}$ \\
\hline $219-15 b$ & $\begin{array}{l}\text { memleketde dincilik ve } \\
\text { refâhiyyet var-ısa }\end{array}$ & $\begin{array}{l}\text { memleketde dinçlik ve } \\
\text { refāhiyyet var-ısa }\end{array}$ \\
\hline 220-16a & $\begin{array}{l}\text { Şükr senüñdür bu zemîn ü bu } \\
\text { zamân }\end{array}$ & $\begin{array}{l}\text { Şükr senündür bu zemīn ü } \\
\text { zamān }\end{array}$ \\
\hline $221-16 b$ & șevâb ve ḳadri ‘azîmdür & șevābı ve ḳadri ‘aẓīmdür \\
\hline $222-17 b$ & ḳalanında daḩı ḩabar oldı & ḳalanına daḩı ḩabar oldı \\
\hline $223-18 a$ & Beşinci ḥikmet budur ki & Bişinci ḥikmet budur ki \\
\hline $224-18 a$ & $\begin{array}{l}\text { bu çirkîn șıfatlaruñ nihâyeti xxx } \\
\text { belî }\end{array}$ & $\begin{array}{l}\text { bu çirkīn șıfatlarun nihayeti } \\
\text { yoḳdur beli }\end{array}$ \\
\hline $224-18 a$ & ya'ni xxx bu çuḳura & ya'nī ki bu çuḳura \\
\hline $224-18 b$ & cem'itdi câdûların & cem`itdi cādūları \\
\hline $226-20 a$ & $\begin{array}{l}\text { Eger ḳuvveti xxx ḳudreti } \\
\text { olmaya }\end{array}$ & Eger ḳuvveti ve ḳudreti olmaya \\
\hline $228-21 a$ & $\begin{array}{l}\text { Kâfiri vü münâfıḳı müşriki } \\
\text { cümle kişi } \\
\text { Cehd id ü kaḥr id anları irkek } \\
\text { ola vü ger kişi }\end{array}$ & $\begin{array}{l}\text { Kāferi vü münāfıkıı müşriki } \\
\text { cümle kişi } \\
\text { Cehd id ü kaḥr id anları irkek } \\
\text { ola vü ger dişi }\end{array}$ \\
\hline $228-21 a$ & Ve xxx ma'nice ġazâ itmekde & Ve bu ma'nīce ġazā itmekde \\
\hline $231-23 a$ & 'inâyet gösterür & 'ināyeti gösterür \\
\hline
\end{tabular}




\begin{tabular}{|c|c|c|}
\hline $231-23 a$ & sülük ehlinüñ & sülūk ehlinün \\
\hline $232-24 a$ & ileyhlerinde ḳodılar & ileylerinde ḳodılar \\
\hline $233-24 a$ & $\begin{array}{l}\text { Hâce Gülşehrî buyurdı } \\
\text { rahimetullah }\end{array}$ & $\begin{array}{l}H^{2} \text { āce Gülşehrī buyurdı } \\
\text { rahimehu'llāh }\end{array}$ \\
\hline $238-27 a$ & giçüt virdiler & geçüt virdiler \\
\hline $239-27 b$ & $\begin{array}{l}\text { cümle-i 'âlem halkıına bir resûli } \\
\text { bir oğurdan viribidiler }\end{array}$ & $\begin{array}{l}\text { cümle-i 'ālem balḳına bir } \\
\text { uġurdan viribidiler }\end{array}$ \\
\hline $240-28 b$ & $\begin{array}{l}\text { xxx âdem oġlanlarınuñ } \\
\text { yigregiyin }\end{array}$ & $\begin{array}{l}\text { eydür ben ādem oġlanlarınun } \\
\text { yigregiyin }\end{array}$ \\
\hline $241-29 a$ & Ḥaḳ ta'âlâ halifalıġıdur & Ḥak te ālānun halïfalıġıdur \\
\hline $243-30 b$ & İçürdi nûşını Nûşîrevân’a & İçürdi nūşını Nūşinrevān’a \\
\hline $245-31 b$ & $\begin{array}{l}\text { Allah subhâne ve ta'âlâ } \\
\text { buyurur: }\end{array}$ & $\begin{array}{l}\text { Allāh subhānehū ve te āalā } \\
\text { buyurur: }\end{array}$ \\
\hline $250-34 b$ & ölicek maḥrûm ola & ölicek merḥūm ola \\
\hline $251-35 a$ & bundan dahı & bunda dahı \\
\hline $252-36 a$ & $\begin{array}{l}\text { 'izzet yolından ve himmet } \\
\text { yolından istemeyeler }\end{array}$ & $\begin{array}{l}\text { 'izzet yolından ve himmet } \\
\text { bolından istemeyeler }\end{array}$ \\
\hline $256-38 a$ & rıżâ virmedi & rıżā virdi \\
\hline $256-38 b$ & ger sürüde ḳoç ola & eger sürüde ḳoç ola \\
\hline $256-38 b$ & ḥamdilillahi ta'âlâ & ḥamdi’llahi te ālā \\
\hline $257-39 a$ & vaḳtında hâżır oldı & vaḳtına hāżır oldı \\
\hline $259-40 a$ & âşikâre itmegi & āşikārā itmegi \\
\hline $264-43 b$ & ârâste gösterürler & ārāste gösterürse \\
\hline $266-45 a$ & Șavaşda urışda ol şîr-i ner & Șavaşda urışda ola şīr-i ner \\
\hline $267-46 a$ & $\begin{array}{l}\text { Bu birkaç beyte naz̧ar ḳılalar: } \\
\text { xxx }\end{array}$ & $\begin{array}{l}\text { Bu birkaç beyte naz̧ar ḳılalar: } \\
\text { şi 'r }\end{array}$ \\
\hline $268-46 b$ & n'idersin şâh sen & n'idesin şāh sen \\
\hline
\end{tabular}




\begin{tabular}{|c|c|c|}
\hline $271-48 a$ & $\begin{array}{l}\text { başını ḳullıg işinden } \\
\text { ḳaldurmaya }\end{array}$ & $\begin{array}{l}\text { başını ḳullıg işiginden } \\
\text { ḳaldurmaya }\end{array}$ \\
\hline $271-48 b$ & Hikmete bil baġladuñsa & Hıdmete bil baġladunsa \\
\hline $272-49 b$ & dâyimâ nâz eylese & dāyim nāz eylese \\
\hline $272-49 b$ & sulțânlıġınuñ yüceligi & sulțānlıġuñ yüceligi \\
\hline $273-50 a$ & zîre kim & zīre ki \\
\hline $273-50 a$ & $\begin{array}{l}\text { Ḥakîikat âdemî Hakaḱdan yüzin } \\
\text { döndüre }\end{array}$ & $\begin{array}{l}\text { Ḥakīịat adamı Haḳ'dan yüzin } \\
\text { döndüre }\end{array}$ \\
\hline $274-50 b$ & Ve dabnı yaḳın bile ki & Ve dahı yaḳin bile ki \\
\hline $274-51 a$ & yâ resûlullah & yā resūla'llāh \\
\hline $284-57 a$ & lems bigi xxx içerüden & lems bigi ve içerüden \\
\hline $293-63 b$ & misḳal žerre & mișḳāle zeerre \\
\hline $293-63 b$ & cehd ideler & cehd iderler \\
\hline $294-64 a$ & kimsenüñ vaḥfına & kimsenün vaḳfına \\
\hline $295-64 b$ & kendü ve mașrafından & kendü mașrafından \\
\hline $295-65 a$ & bu işüñ arasında ola & bu işüñ edāsında ola \\
\hline $296-65 b$ & Mıșr mülkin duta & Mıșr mülkin dutdı \\
\hline $298-66 b$ & Nice $\mathbf{x x x}$ eydür: & Nice ki eydür: \\
\hline $299-67 b$ & âkil veyâ mümeyyiz & 'āḳil ve mümeyyiz \\
\hline $300-68 a$ & ḳatı hașm u kîn ola & ḳatı haşm u kīn ola \\
\hline $302-69 b$ & bunuñ gibi & bunun bigi \\
\hline $303-70 a$ & $\mathbf{x x x}$ & $\begin{array}{l}\text { ve șalla'llāhu 'alā seyyidinā } \\
\text { muḥammedin ve ālihī ecma īn }\end{array}$ \\
\hline $306-71 a$ & vezîrân fi's-semâ & vezīiāni fi's-semā \\
\hline $306-71 a$ & ‘Ömer Hațțâb & 'Ömerü Hațțāb \\
\hline $308-72 b$ & Şerî‘at caddesinde țoġrıl & şerīat cāddesine țoġrıl \\
\hline
\end{tabular}




\begin{tabular}{|c|c|c|}
\hline $309-73 a$ & ġırra ḳılmak & ġarra ḳılmak \\
\hline $312-74 b$ & $\begin{array}{l}\text { yimege ve içmege } \mathbf{x x x} \\
\text { tecemmüle }\end{array}$ & $\begin{array}{l}\text { yimege ve içmege ve } \\
\text { tecemmüle }\end{array}$ \\
\hline $313-75 b$ & anı götürmekden âcizdür xxx & anı götürmekden ‘ãcizdür ki \\
\hline $314-76 b$ & şol ḳabileden olur ki & şol kabīilden olur ki \\
\hline $315-77 a$ & pâdişâh hażretinden & pāžişāh hażretinde \\
\hline $316-78 a$ & aḥsenin vech-ile & aḥsen-i vech-ile \\
\hline $318-79 a$ & $\begin{array}{l}\text { Şahlar işiginde iy sâabit-ḳadem } \\
\text { budur șebât }\end{array}$ & $\begin{array}{l}\text { Şahlar işiginde iy șāḥib-ḳadem } \\
\text { budur șebāt }\end{array}$ \\
\hline $318-79 b$ & $\begin{array}{l}\text { bir kişiye dab̧ı xxx mahalli } \\
\text { degüldi }\end{array}$ & $\begin{array}{l}\text { bir kişiye dahı ki mahalli } \\
\text { degüldi }\end{array}$ \\
\hline $319-79 b$ & hasm ve kîn kxoparur & haşm ve kīn kxoparur \\
\hline $319-80 a$ & $\begin{array}{l}\text { mașlaḥatlu re'y-ile ol hâlete } \\
\text { tedârik itmege }\end{array}$ & $\begin{array}{l}\text { mașlaḥatlu rāy-ile ol hāalete } \\
\text { tedārük itmege }\end{array}$ \\
\hline $319-80 a$ & $\begin{array}{l}\text { her yara ki andan daġ urmak } \\
\text { gerek }\end{array}$ & $\begin{array}{l}\text { her yara kim anda daǵ urmak } \\
\text { gerek }\end{array}$ \\
\hline $320-80 b$ & țarafında ola & țarafına ola \\
\hline $322-82 a$ & andadur ki işleri & andandur ki işleri \\
\hline $323-83 a$ & ḥâciblerüñ takssîrindedür & ḥāciblerün taḳsírindendür \\
\hline $328-86 a$ & $\begin{array}{l}\text { Var ni ḥırș u ḥažzz-ı nefs atına } \\
\text { ardarsañ ayaḳ }\end{array}$ & $\begin{array}{l}\text { Verni ḥırș u hazazz-ı nefs atına } \\
\text { ardarsan ayak }\end{array}$ \\
\hline $334-88 a$ & tâbi'în ve ilerüki eyyime & tābi'în ve ilerüki e'imme \\
\hline $335-89 b$ & ve $\mathbf{x x x}$ ma'rifet 'ilmi & ve gönül ma'rifet 'ilmi \\
\hline $336-90 a$ & hitâbet ve nîdâ ve hâḳıf & hițābet ve nidā ve hātıf \\
\hline $336-90 a$ & fenâ'l-fenâ 'ilmi ve bekâ 'ilmi & fenā 'ilmi ve beḳā 'ilmi \\
\hline $338-91 a$ & íkinci ol ki & ìkinç ol ki \\
\hline $338-91 a$ & bu üçinci nâdirdür & bu üçinç nādirdür \\
\hline
\end{tabular}




\begin{tabular}{|c|c|c|}
\hline $339-91 b$ & ḳutb-ı vaḳt xxx ola & ḳuțb-ı vaḳt ol ola \\
\hline $339-91 b$ & xxx peygâmbarlaruñ & ve peygāāmbarlarun \\
\hline $340-92 b$ & $\begin{array}{l}\text { Çün şekl-i ‘ulūmı ḥall ḳılur } \\
\text { Ol 'ilm-ile hoș ‘amel ḳılur }\end{array}$ & $\begin{array}{l}\text { Çün şekl-i ‘ulūmı hạall ḳılurlar } \\
\text { Ol 'ilm-ile hōş 'amel ḳılurlar }\end{array}$ \\
\hline $34092 b$ & halk ḳabūlın ‘ilm tîg̀-ıla & ḩalḳ ḳabūlın ‘ilmi tig̀̀yla \\
\hline $342-94 a$ & bunlar sâbit iderler & bunlarda șābit iderler \\
\hline $343-94 a$ & ḩatalarınun sevâbına & ḩațālarınun șavābına \\
\hline $343-94 b$ & maġbūn ve maḥrūm ḳıldılar & maġbūn ve maḥrūm ḳaldılar \\
\hline $345-96 a$ & Ḥaḳ sübhâne ve ta'âlâ & Ḥaḳ sübḥānehū ve te'ālā \\
\hline $\begin{array}{l}353- \\
101 a\end{array}$ & cehl-ile bunlaruñ almaduġı & cehl-ile bunlarun aldamaġ \\
\hline $\begin{array}{l}353- \\
101 a\end{array}$ & ḳabūl bulurlar & ḳabūl bulalar \\
\hline $\begin{array}{l}353- \\
101 a\end{array}$ & manșıb ehlinüñ ve fâżıllaruñ & manșıb ehlinün ve ḳāḍ̂ilarun \\
\hline $\begin{array}{l}354- \\
102 a\end{array}$ & minbere çılıup & menbere çıḳup \\
\hline $\begin{array}{l}358- \\
104 b\end{array}$ & iḥtirâz ideler & iḥtirāz iderler \\
\hline $\begin{array}{l}359- \\
105 a\end{array}$ & ḳurbet ḥâșıl olur ki & ḳurbet ḥāṣıl olur \\
\hline $\begin{array}{l}360- \\
105 b\end{array}$ & tecellîsi pertevinden & tecellīsi pertevinde \\
\hline $\begin{array}{l}362- \\
107 a\end{array}$ & İkileyin vilâyet emceginden & İki lebin vilāyet emceginden \\
\hline $\begin{array}{l}364- \\
108 b\end{array}$ & $\begin{array}{l}\text { Benem ol hümâ-yı devlet kî bu } \\
\text { âşinâya geldüm }\end{array}$ & $\begin{array}{l}\text { Benem ol hümā-yı devlet ki bu } \\
\text { āşiyāna geldüm }\end{array}$ \\
\hline $\begin{array}{l}367- \\
110 b\end{array}$ & $\begin{array}{l}\text { Hâşâ ol kim Haḳ işidür } \\
\text { bilmedin }\end{array}$ & $\begin{array}{l}\text { Hāṣa ol kim Haḳ işidür } \\
\text { bilmedin }\end{array}$ \\
\hline
\end{tabular}




\begin{tabular}{|c|c|c|}
\hline $\begin{array}{l}367- \\
111 a\end{array}$ & vereseler mâlından & vereșeler mālında \\
\hline $\begin{array}{l}369- \\
112 a\end{array}$ & Dūzaḩ adı & Dūzaḩ odı \\
\hline $\begin{array}{l}370- \\
113 a\end{array}$ & müdde'î ve müdde'î-i ‘aleyh & müdde'ī ve müdde'à 'aleyh \\
\hline $\begin{array}{l}371- \\
114 a\end{array}$ & teblîse meşgūl olımazlar. & telbīse meşgūl olımazlar. \\
\hline $\begin{array}{l}372- \\
114 a\end{array}$ & ol xxx ḳıyâm göstere & ol işe ḳıyām göstere \\
\hline $\begin{array}{l}373- \\
115 a\end{array}$ & sırran ve 'aleniyyeten & sırran ve 'alāniyyeten \\
\hline $\begin{array}{l}374- \\
116 a\end{array}$ & ḥaḳ ta'âlâ hażretinden & ḥaḳ te ālā hażretinde \\
\hline
\end{tabular}

\section{Kaynakça}

Şeyhoğlu Mustafa (2013). Kenzü'l-Küberâ ve Mehekkü'l-Ulemâ (Büyüklerin Hazinesi ve Âlimlerin Mihenk Taşı), haz. Kemal Yavuz. İstanbul: Büyüyen Ay Yayınları.

YAVUZ, Kemal (1991). Şeyhoğlu Kenzü'l-Küberâ ve Mehekkü'l-Ulemâ. Ankara: Atatürk Kültür Merkezi Yayınları 


\section{EKLER}

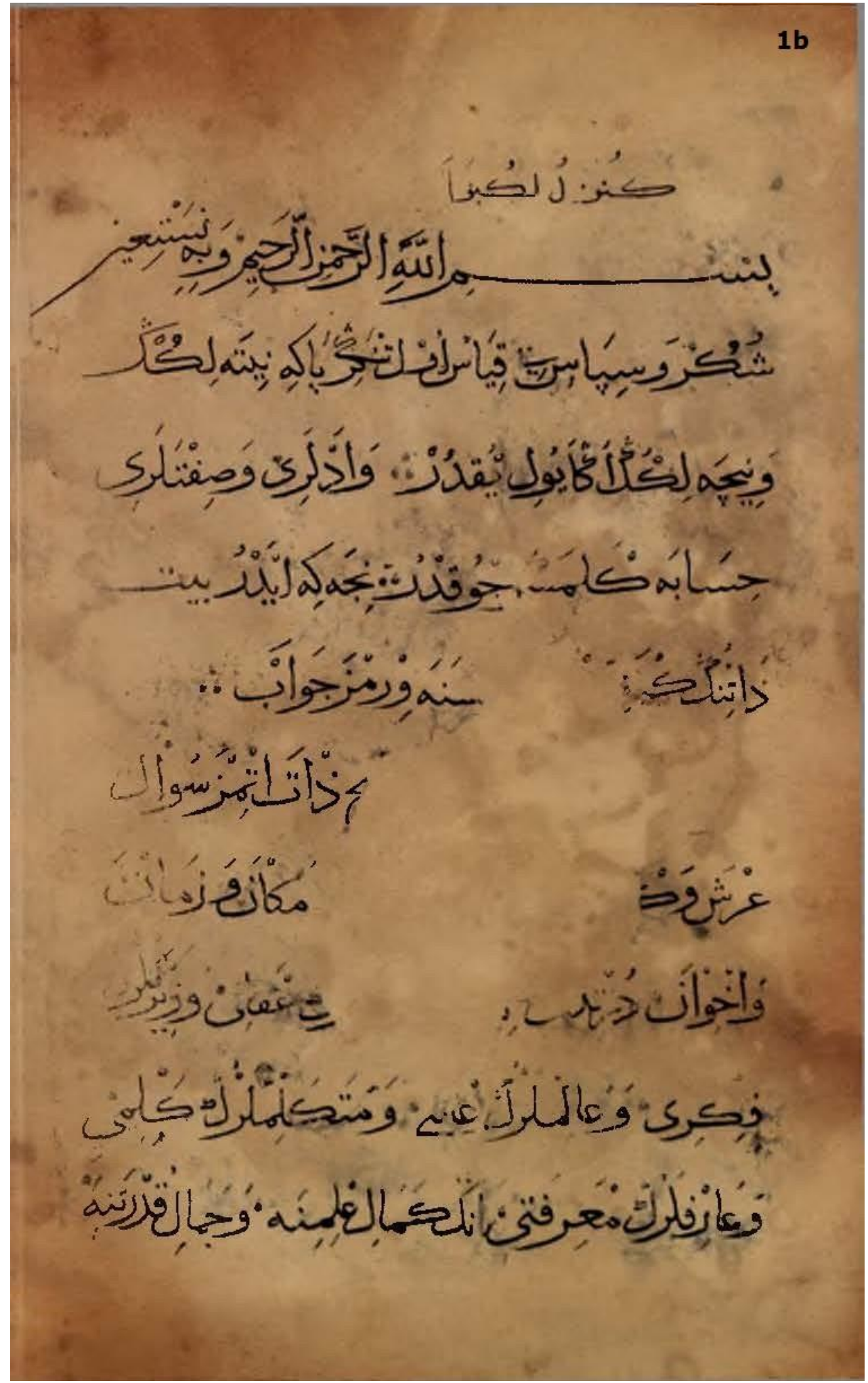




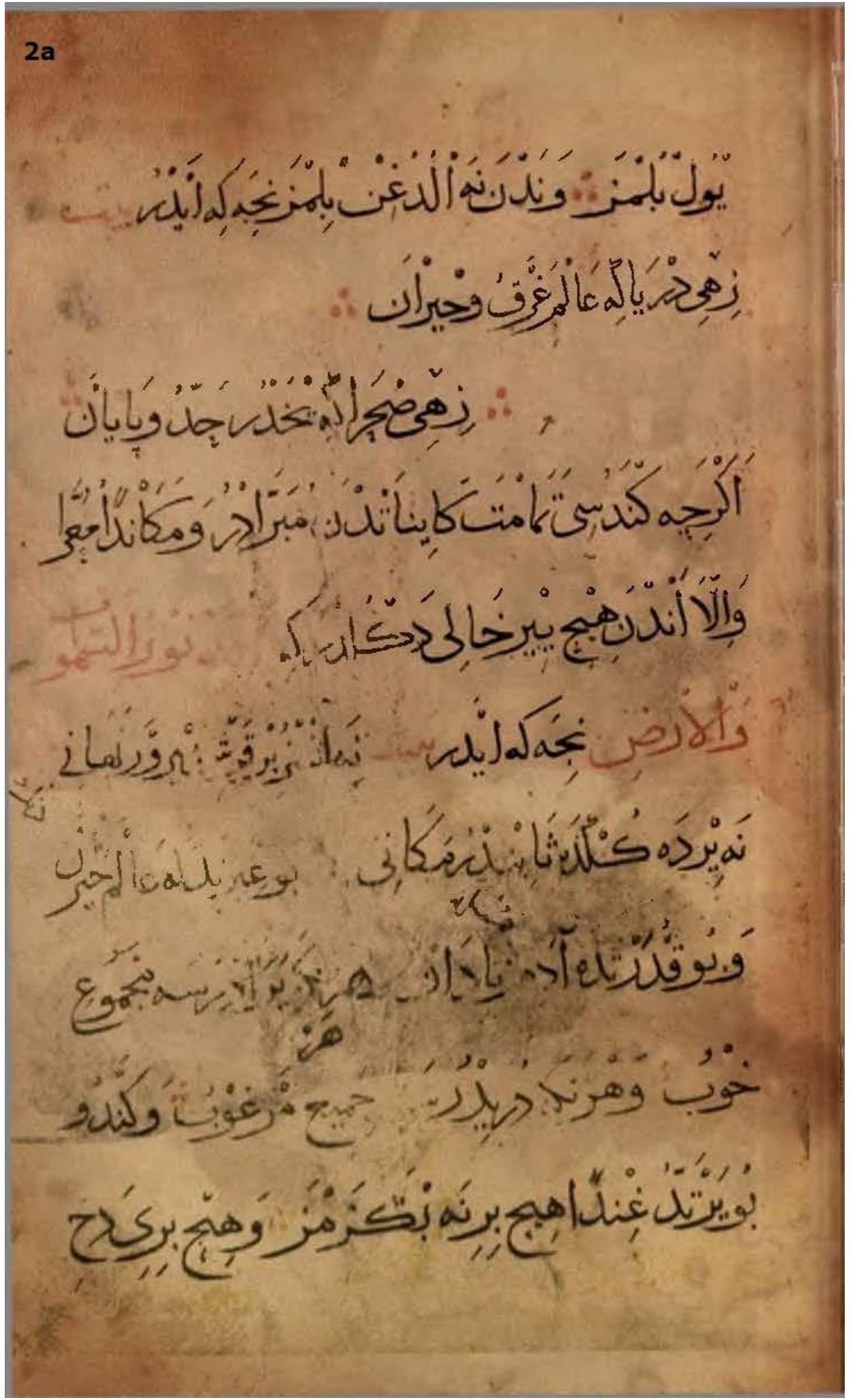

